\title{
Growth of freshwater Etheria elliptica oyster (Lamarck, 1807) reared in cages in the Pendjari River (Benin, West Africa)
}

\author{
Giraud David Akélé ${ }^{1,2, *}$, Simon Ahouansou Montcho ${ }^{1,2}$ and Philippe Adédjobi Lalèyè ${ }^{1}$ \\ ${ }^{1}$ Laboratoire d'Hydrobiologie et d'Aquaculture, Faculté des Sciences Agronomiques, Université d'Abomey-Calavi, \\ 01 BP 526 Cotonou, Benin \\ ${ }^{2}$ Ecole d'Aquaculture de la Vallée, Université Nationale d'Agriculture, BP 43 Kétou, Benin
}

Received 3 December 2015 / Received in final form 23 March 2017 / Accepted 23 March 2017

\begin{abstract}
In this paper, we assess the growth performance, survival rate and abiotic factors affecting Etheria elliptica (Mollusca: Bivalvia: Etheriidae), the African freshwater oyster, a species that is widespread in tropical Africa where it is widely harvested for food and as a commodity. We collected wild oysters from the Pendjari River (Benin) and grouped them into small $(23.4 \pm 5.2 \mathrm{~mm})$ and large $(55.8 \pm 7.7 \mathrm{~mm})$ size classes. They were reared in cages in the Pendjari River from January to December 2009. Shell height was measured on a monthly basis, and estimated growth parameters were assessed using the von Bertalanffy growth function. Overall, the growth parameter estimates for pooled size classes were $K=0.0718 \mathrm{month}^{-1}$ and $L_{\infty}=82.2 \mathrm{~mm}$. We estimated the time to reach minimum commercial size $T_{65 \mathrm{~mm}}$ (female sexual maturity size) to be 22 months (1.8 years). Small oysters exhibited a peak in growth rate $\left(2.775 \mathrm{~mm} \mathrm{month}^{-1}\right)$ in May, whereas large-sized oysters grew fastest $\left(1.707-2.781 \mathrm{~mm} \mathrm{month}^{-1}\right)$ in August-September during the rainy/ flood season. Survival of small-sized oysters declined sharply from May $(60 \%)$ to June $(11 \%)$ at the onset of the rainy season, six months after the beginning of experiment, while large oysters had higher survival in June $(79.2 \%)$, which decreased in December (26.4\%). Among abiotic factors investigated, water transparency was negatively correlated with the growth increment of small-sized oysters $(p<0.05) . E$. elliptica is a suitable candidate for culture due to its large maximum size, reasonable growth rate, and wide geographic range.
\end{abstract}

Keywords: freshwater bivalve / Etheriidae / Unionoida / survival / aquaculture

Résumé - L'huître africaine d'eau douce Etheria elliptica (Mollusca: Bivalvia: Etheriidae) présente une large distribution en Afrique tropicale. L'huître est exploitée par les communautés locales à des fins alimentaires et économiques. Dans cette étude, nous avons évalué les performances de croissance, le taux de survie et les facteurs abiotiques qui affectent la croissance de l'huître en milieu naturel. Les huîtres ont été réparties en spécimens de petites $(23,4 \pm 5,2 \mathrm{~mm})$ et grandes tailles $(55,8 \pm 7,7 \mathrm{~mm})$. Elles ont été élevées en cages dans la rivière Pendjari de janvier à décembre 2009. La hauteur de la coquille a été mesurée tous les mois. Les paramètres de croissance ont été estimés avec l'équation de von Bertalanffy. Les paramètres de croissance globale (toutes tailles confondues) ont été estimés à $\mathrm{K}=0,0718 \mathrm{mois}^{-1}$ et $L_{\infty}=82,2 \mathrm{~mm}$. Le temps nécessaire $\left(T_{65 \mathrm{~mm}}\right)$ aux juvéniles pour atteindre la taille de maturité sexuelle femelle (considérée comme la taille minimale de récolte) a été estimé à 22 mois ( 1,8 ans). Le taux d'accroissement mensuel des huîtres de petites tailles a atteint une valeur maximale $\left(2,775 \mathrm{~mm} \mathrm{mois}^{-1}\right)$ en mai alors que les spécimens de grandes tailles ont affiché un taux d'accroissement élevé $\left(1,707-2,781 \mathrm{~mm} \mathrm{mois}^{-1}\right)$ pendant la saison des pluies et des crues en août-septembre. Par contre, le taux de survie a connu une baisse significative chez les petites huîtres après six (6) mois d'élevage, décroissant de $60 \%$ en mai à un minimum de $11 \%$ en juin au début de la saison des pluies. Chez les individus de grandes tailles, le taux de survie est apparu plus élevé en juin $(79,2 \%)$ avant de décroître en décembre $(26,4 \%)$. Parmi les variables environnementales enregistrées, seule la transparence de l'eau a été négativement corrélée avec la taille moyenne des huitres de petite taille $(p<0,05)$. L'étude a révélé que l'huître d'eau douce E. elliptica est un candidat potentiel pour l'aquaculture en raison de son taux de croissance proche de celui des huîtres commerciales actuellement élevées, de la

\footnotetext{
* Corresponding author: akeldav@yahoo.fr
} 
grande taille des individus et de sa large répartition géographique. L'ostréiculture traditionnelle dans la rivière Pendjari devrait être entreprise pour augmenter la production d'huîtres.

Mots-clés : Bivalve d'eau douce / Etheriidae / Unionoida / survie / aquaculture

\section{Introduction}

In tropical areas, bivalves such as oysters and clams are exploited for human consumption and as a source of income for local communities (Ajana, 1980; Diadhiou, 1995; Thiam et al., 2011). Although there have been many attempts at oyster culture throughout Africa, most bivalve production is still from harvesting of wild stocks (Kamara, 1982; Vakily, 1992; Diadhiou, 1995). Many commercially important tropical oysters exhibit extremely fast growth relative to temperate species, and achieve market-size in less than one year, often in as little as six months (Quayle, 1980; Angell, 1986; Thiam et al., 2011). However, fishery production has not met market demand. Therefore, we require more data to evaluate candidate bivalve species for aquaculture (Diadhiou, 1995; Cáceres-Puig et al., 2007).

In West Africa, most commercially important bivalve populations are overexploited due not only to the harvest of immature individuals (Adjei-Boateng and Wilson, 2013; Akélé et al., 2015) but also to local human population growth (Ajana, 1980; Adjei-Boateng and Wilson, 2012, 2013). The traditional method of culturing bivalves under natural conditions without food supplementation has been reported to be beneficial in several studies (Ansa and Bashir, 2007; Adjei-Boateng and Wilson, 2012; Adjei-Boateng and Wilson, 2013; Crow and Carney, 2013).

Developing bivalve culture requires technical data on the growth performance and survival of species under culture systems (Angell, 1986; Urban, 2000; Adjei-Boateng and Wilson, 2013). Various studies have focused on the mangrove oyster Crassostrea gasar (Ajana, 1980; Ansa and Bashir, 2007) and the freshwater clam Galatea paradoxa (King, 2000; Adjei-Boateng and Wilson, 2012; Adjei-Boateng and Wilson, 2013) to ascertain their growth rates and culture potential. Mangrove oysters, $C$. gasar, grow quickly and are a suitable candidate for culture in African estuaries (Diadhiou, 1995; Ansa and Bashir, 2007). Likewise, G. paradoxa grows well and was recommended for traditional aquaculture in Ghana (Adjei-Boateng and Wilson, 2013). In Casamance (Senegal), C. gasar reached a commercial size of $6 \mathrm{~cm}$ in 18 months under culture conditions (Diadhiou, 1995). In Nigeria, Ajana (1980) reported 7-8 months to attain commercial size $(6-7 \mathrm{~cm})$ for $C$. gasar. In the Volta River (Ghana), the freshwater clam G. paradoxa reached a marketable size of $5 \mathrm{~cm}$ in 4 years (Adjei-Boateng and Wilson, 2013). In addition, many studies have focused on how environmental factors influence bivalve growth in tropical areas (Vakily, 1992; Adjei-Boateng and Wilson, 2012). Their results revealed flood/ rain seasonality as the primary influence on bivalve growth rates in tropical zones (Adjei-Boateng and Wilson, 2013). In contrast, water temperature appears to greatly influence the growth rate in temperate areas (Lango-Reynoso et al., 2000).

Etheria elliptica (Mollusca: Bivalvia: Etheriidae) is a freshwater oyster largely distributed in tropical Africa and Madagascar (Graf and Cummings, 2006; Van Damme, 2011). Etheria elliptica belongs to the order Unionoida also known as freshwater mussels (Graf and Cummings, 2006). In West
Africa, it is widely harvested as a source of protein and income in many local fisheries (Ampofo-Yeboah et al., 2009; Ikpi and Offem, 2012) and has been overexploited (Poda, 1992; Akélé et al., 2015). Surprisingly, unlike other economically important bivalves, little research has been conducted on the biology, growth performance and culture potential of this bivalve. Abell et al. (1996) reported the influence of monthly lunar cycles on oyster growth in Lake Victoria, while Ampofo-Yeboah et al. (2009) dealt with its reproduction in northern Ghana.

In Benin, E. elliptica is harvested year-round in the Pendjari River by local communities for food and commerce (Akélé et al., 2015). Oysters are mostly collected within the Pendjari Biosphere Reserve (PBR), a protected area crossed by the Pendjari River. Local inhabitants are granted access to the protected area in return for their contribution to anti-poaching and conservation activities (Vodouhê et al., 2009). Consequently, a collapse of this oyster resource would likely impact not only human livelihoods but also the incentive of the local population to protect wildlife against poaching. Therefore, developing oyster culture is important for both the local population and PBR management staff. The present study aims to assess the growth performance and culture potential of E. elliptica under natural conditions in the Pendjari River. Specifically, we estimate the von Bertalanffy growth function (VBGF) parameters $K$ and $L_{\infty}$ of large and small oysters, and the time required to reach female maturity (minimum marketable size), and analyze seasonal variation in growth rate to evaluate the effect of environmental variables on oyster growth.

\section{Material and methods}

\subsection{Study site}

We conducted our experiments at Porga station $\left(11^{\circ} 02^{\prime} \mathrm{N}\right.$ and $0^{\circ} 57^{\prime}$ E; Fig. 1) in the Pendjari River, a tributary of the Volta basin system (Barry et al., 2005). This river is located in the Sudanian climatic zone characterized by one rainy season (May/June to October) and one dry season (November to March/April). Temperatures are highest in March, April and May and lowest in December, January and February during the Harmattan, a very dry and dusty easterly or north-easterly wind occurring from December to February (Barry et al., 2005). Mean rainfall is approximately $1000 \mathrm{~mm}$ annually with $60 \%$ falling between July and September. Temperatures in the area vary between $11^{\circ} \mathrm{C}$ (at night) and $40^{\circ} \mathrm{C}$ (Sinsin et al., 2002). The Pendjari River has a tropical hydrological regime with a low water season between December and June and a flood season from September to October. The river bottom at the experimental site is sandy and rocky.

\subsection{Sampling and cage rearing}

Lévêque (1971) recommends that the growth rate of longlived bivalve molluscs be estimated using different size groups. We collected E. elliptica in the Pendjari River in January 2009 at the end of flood season, and divided the specimens into two 


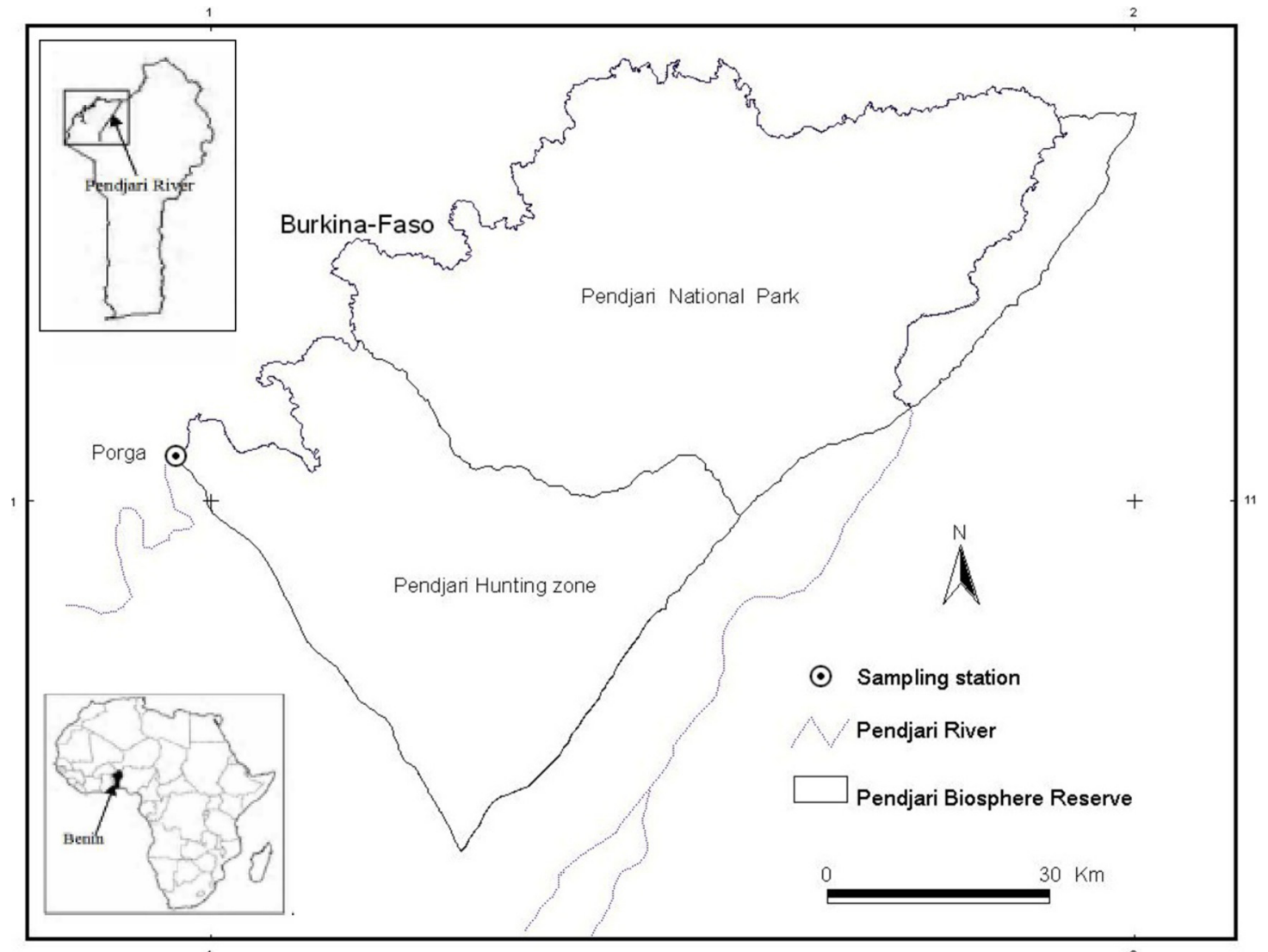

Fig. 1. Location of sampling station in the Pendjari River (Benin, West Africa).

groups according to their shell size: small and large. We measured shell height (size from the tip of the umbonal end of the upper valve to the ventral margin) to the nearest $1.0 \mathrm{~mm}$. Overall, 98 oyster specimens were reared in wooden cages $(75 \mathrm{~cm} \times 50$ $\mathrm{cm} \times 50 \mathrm{~cm})$ at the bottom of the Pendjari River. The cages were surrounded with wire grids to prevent predation and loss (Lévêque, 1971). The two size classes were chosen for their availability and the difficulty in finding smaller individuals, which are initially brooded in marsupial gills and later are obligate parasites of fish hosts (Kenmuir, 1980; Graf and Cummings, 2006). Experimental oyster densities in the cages was similar to that observed in natural colonies ( $0.5-6.5$ oysters/ $\mathrm{m}^{2}$ ) (Akélé et al., 2015). Field work was carried out only at Porga station, near the encampment of fishermen who were responsible for surveillance and protection of the cages. The experiment station was located close to housing and was therefore subject to human activities such as clothes washing, bathing, and watering livestock, while experiments at two other sites located within the Pendjari Biosphere Reserve were terminated due to the theft of experimental material.

\subsection{Data collection}

We conducted our experiments from January to December 2009. All animals were tagged with indelible red ink in January 2009 and held in cages at the bottom of the river. Tags were remade during each measurement to ensure they were readable. We measured shell height monthly using a Vernier caliper. At each measurement, we also recorded the number of dead individuals, which are removed from the cages.

The growth of bivalves is affected by abiotic factors. Therefore, we monitored several environmental variables such as water temperature, dissolved oxygen $\left(\mathrm{mg} \mathrm{L}^{-1}\right)$, hydrogen ion concentration $(\mathrm{pH})$, total dissolved solids (TDS) $\left(\mathrm{mg} \mathrm{L}^{-1}\right)$, conductivity $\left(\mu \mathrm{S} \mathrm{cm}^{-1}\right)$ and transparency $(\mathrm{cm})$ monthly from January 2009 to December 2009 at Porga station. Water temperature $\left({ }^{\circ} \mathrm{C}\right), \mathrm{pH}, \mathrm{TDS}\left(\mathrm{mg} \mathrm{L}^{-1}\right)$ and conductivity $\left(\mu \mathrm{S} \mathrm{cm}^{-1}\right)$ were recorded at the bottom of the water with $\mathrm{pH} / \mathrm{EC} / \mathrm{TDS} / \mathrm{Temperature}$ meters (HANNA Combo HI98129). Dissolved oxygen $\left(\mathrm{mg} \mathrm{L}^{-1}\right)$ at the bottom of the site was measured using an oxygen measuring instrument (DO-100 Voltcraft). Water transparency was estimated with a Secchi disc to the nearest $1 \mathrm{~cm}$.

\subsection{Data analysis}

We fit a von Bertalanffy growth function (VBGF) and growth rate index to our data to assess growth of the two size groups of oysters (Lévêque, 1971; Hastie et al., 2000; Haag, 2009). The VBGF is $L_{t}=L_{\infty}\left(1-e^{-K t}\right)$, where $L_{t}$ is the length at age $t, L_{\infty}$ is the asymptotic size $(\mathrm{mm})$, and $K$ is the growth coefficient per month, which measures the exponential rate of approach to the asymptotic size (von Bertalanffy, 1938). We estimated the two VBGF growth parameters $L_{\infty}$ and $K$ using a Ford-Walford plot (Walford, 1946), where length at age $t\left(L_{t}\right)$ is plotted against length $\left(L_{t+1}\right)$ at $t+1$ month. The regression 
Table 1. Value of von Bertalanffy growth parameters of two size groups of the freshwater E. elliptica oyster reared in cages in the Pendjari River (Benin) from January to December 2009.

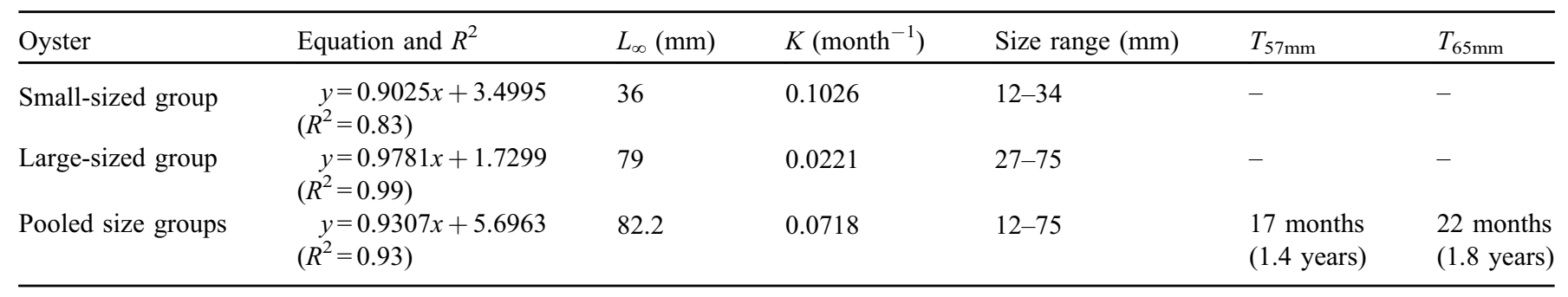

line equation of best fit was estimated as $Y=\alpha+\beta x$, where $\beta$ is the slope and $\alpha$ is the intercept of best-fit line on the $y$-axis. $L_{\infty}$ is given by $L_{\infty}=[\alpha /(1-\beta)]$ and the growth constant $K$ is computed as the natural $\log$ of the slope inverse $K=\ln (1 / \beta)$ (Gulland, 1969). We estimated VBGF growth parameters separately for the two size groups and then overall for all experimental oysters. The overall growth parameters were used to estimate the number of months required to reach the size at sexual maturity $\left(T_{57 \mathrm{~mm}}\right.$ for males and $T_{65 \mathrm{~mm}}$ for females) in the study area (Akélé, 2015). The monthly survival rate in percentage accounted for the number of survivors out of the initial specimens.

We estimated the mean growth rate (GR) using the formula $\mathrm{GR}=\left(X_{t+1}-X_{t}\right) / D$, where $X_{t+1}$ is the mean shell size $(\mathrm{mm})$ of the current month, $X_{t}$ is the shell length of the previous month and $D$ is the number of days between consecutive observations (Paterson et al., 2003). The mean GR was then used to assess the influence of environmental variables on the monthly growth of the two oyster groups.

All statistical analyses were performed using Statistica software (version 6). Non-parametric Kruskal-Wallis analyses were used to analyze both growth rate changes and mean variations of environmental factors over the experimental period. Spearman rank correlation analysis was used on monthly averages to investigate the relative effects of environmental variables on the growth rate of different oyster cohorts.

\section{Results}

\section{1 von Bertalanffy growth parameters and survival rate}

The small sized-oysters range from 12 to $34 \mathrm{~mm}$ (initial mean size \pm standard deviation (SD): $23.4 \pm 5.2 \mathrm{~mm} ; n=45$ ), while the large sized-oysters cover the range of $27-75 \mathrm{~mm}$ (initial mean size $\pm \mathrm{SD}$ : $55.8 \pm 7.7 \mathrm{~mm} ; n=53$ ). The mean of pooled size classes was $40.9 \pm 17.5 \mathrm{~mm}$ (size range: 12-75 $\mathrm{mm} ; n=98)$.

The VBGF growth coefficient was about 5 times higher in small-sized oysters $\left(K=0.1026\right.$ month $\left.^{-1}\right)$ than in large-sized oysters $\left(K=0.0221\right.$ month $^{-1}$; Table 1$)$. The global growth coefficient for the two pooled oyster groups was intermediate $\left(K=0.0718 \mathrm{month}^{-1}\right)$. Predicted $L_{\infty}$ was attained at $36 \mathrm{~mm}$ and $79 \mathrm{~mm}$ for small-sized and large-sized oysters, respectively and the global asymptotic value was estimated as $L_{\infty}=82.2 \mathrm{~mm}$. Based on global VBGF parameters, the time to reach male maturity size $\left(T_{57 \mathrm{~mm}}\right)$ was 17 months (1.4 years), whereas the estimated time $\left(T_{65 \mathrm{~mm}}\right)$ to reach female maturity

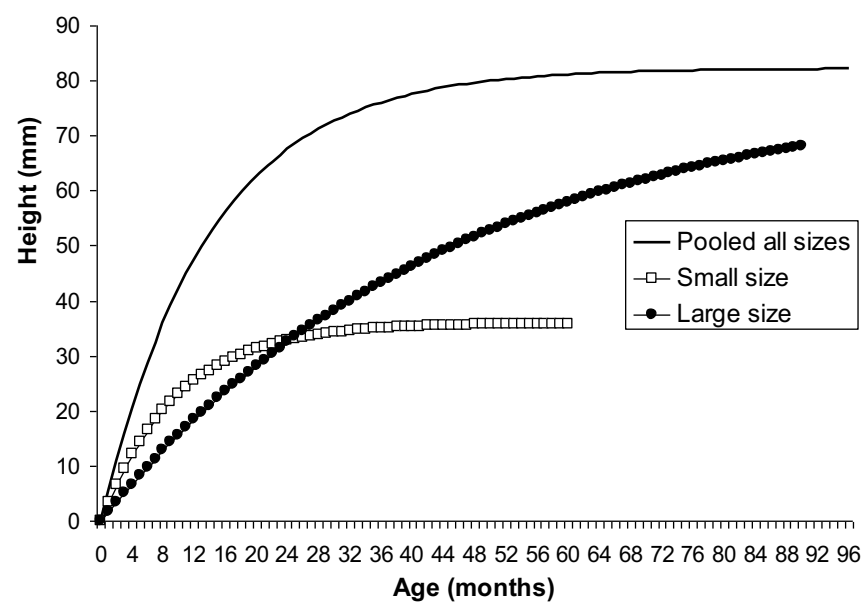

Fig. 2. Height at age growth curves of small-sized group, large-sized group and both groups of freshwater E. elliptica oysters combined. Oysters were reared in cages in the Pendjari River from January to December 2009.

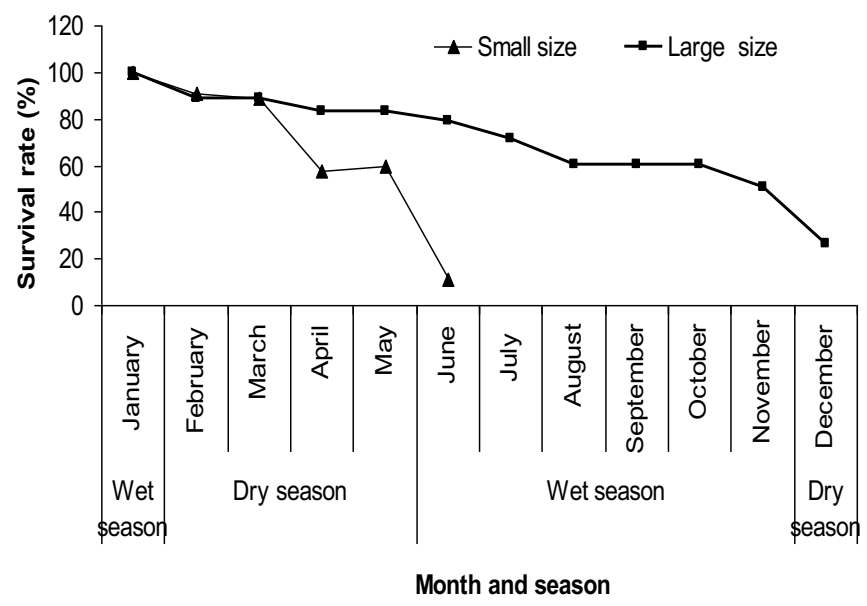

Fig. 3. Survival rate of small- and large-sized groups of freshwater $E$. elliptica oysters reared in cages for one year, from January to December 2009, in the Pendjari River (Benin).

size was 22 months (1.8 years; Fig. 2). The survival rate was lower for small-sized oysters, and all small specimens died after 6 months in July 2009 (Fig. 3). Survival was greater for large oysters $(79.6 \%)$ than for small ones $(11.1 \%)$ in June 2009 (Fig. 3). 


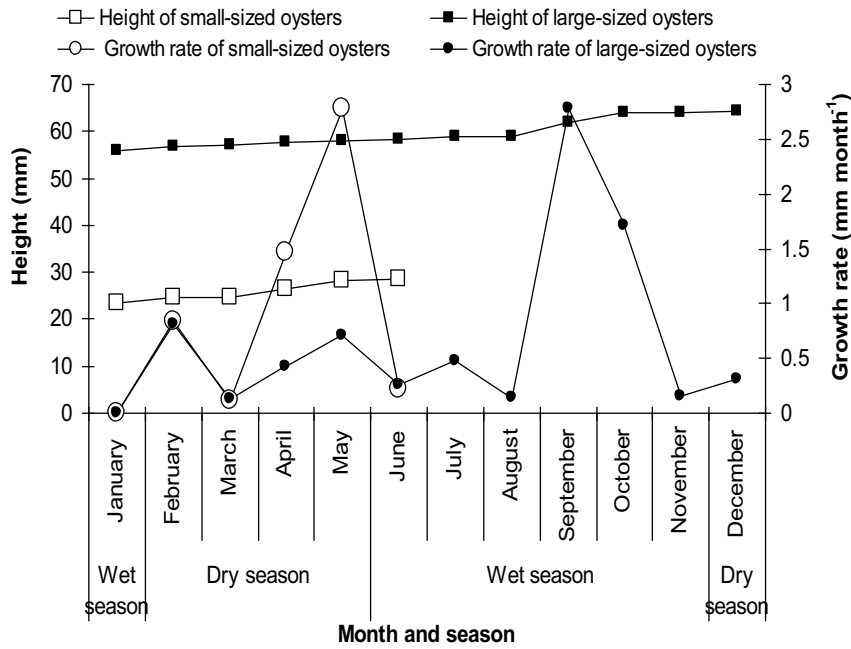

Fig. 4. Mean height increment and growth rates of small-sized and large-sized individuals of E. elliptica held in cages from January to June 2009 in the Pendjari River (Benin).

\subsection{Monthly variations of height and growth rates}

Small oysters grew at a mean rate of $0.85 \mathrm{~mm} \mathrm{month}^{-1}$ from January to June (Fig. 4) for a mean increase of $5.1 \mathrm{~mm}$ during this period. Large-sized oysters grew at a mean rate of $0.71 \mathrm{~mm}$ month $^{-1}$ during the same period for a mean increase of $2.6 \mathrm{~mm}$ from January to June. The mean increase is estimated to $8.5 \mathrm{~mm}$ over 12 months of experimentation. The large-sized oysters grew fastest from July to December 2009 (5.5 mm), coinciding mainly with the flood season (August, September and October). Monthly shell height increased significantly between the two groups across different months $(p<0.05)$. Small-sized oysters displayed a slight increase in growth rate $\left(0.833 \mathrm{~mm} \mathrm{month}^{-1}\right)$ in February 2009 at the beginning of the study and reached a peak in April $\left(1.463 \mathrm{~mm} \mathrm{month}^{-1}\right)$ and May $\left(2.775 \mathrm{~mm} \mathrm{month}^{-1}\right)$ before the death of all specimens in July 2009 (Fig. 4). The growth rate of large-sized oysters increased in February 2009 $\left(0.807 \mathrm{~mm} \mathrm{month}^{-1}\right)$ as for smaller oysters, and declined to their lowest value in March $2009\left(0.127 \mathrm{~mm} \mathrm{month}^{-1}\right)$. However, maximum growth rates of larger oysters were recorded in September $\left(2.781 \mathrm{~mm} m o n t h^{-1}\right)$ and October $(1.707 \mathrm{~mm}$ month $^{-1}$ ) during the peak rainy/flood period (Fig. 4).

\subsection{Environmental variables and oyster growth}

We found seasonal variation for all environmental parameters (Kruskal-Wallis tests, $p>0.05, \mathrm{df}=11$ ) (Fig. 5). Water temperature varied between $23.8^{\circ} \mathrm{C}$ in December during the Harmattan period and $31{ }^{\circ} \mathrm{C}$ in May during the peak of the dry season, with a mean value of $28.7 \pm 2.5^{\circ} \mathrm{C}($ mean $\pm \mathrm{SD})$ (Fig. 5A). Water transparency declined to its lowest values $(10 \mathrm{~cm})$ in July at the onset of the rainy season and reached a peak value $(32 \mathrm{~cm})$ in September during the flood period (Fig. 5A). Water $\mathrm{pH}$ varied only slightly between months $(7.6 \pm 0.1)$. However, $\mathrm{pH}$ increased in May before the onset on the rainy season, and also in December and January when the flood was receding (Fig. 5B). Water depth showed lowest values $(1.1-1.5 \mathrm{~m})$ in the low water level period (January-May, December), increased with the onset of the rainy season in
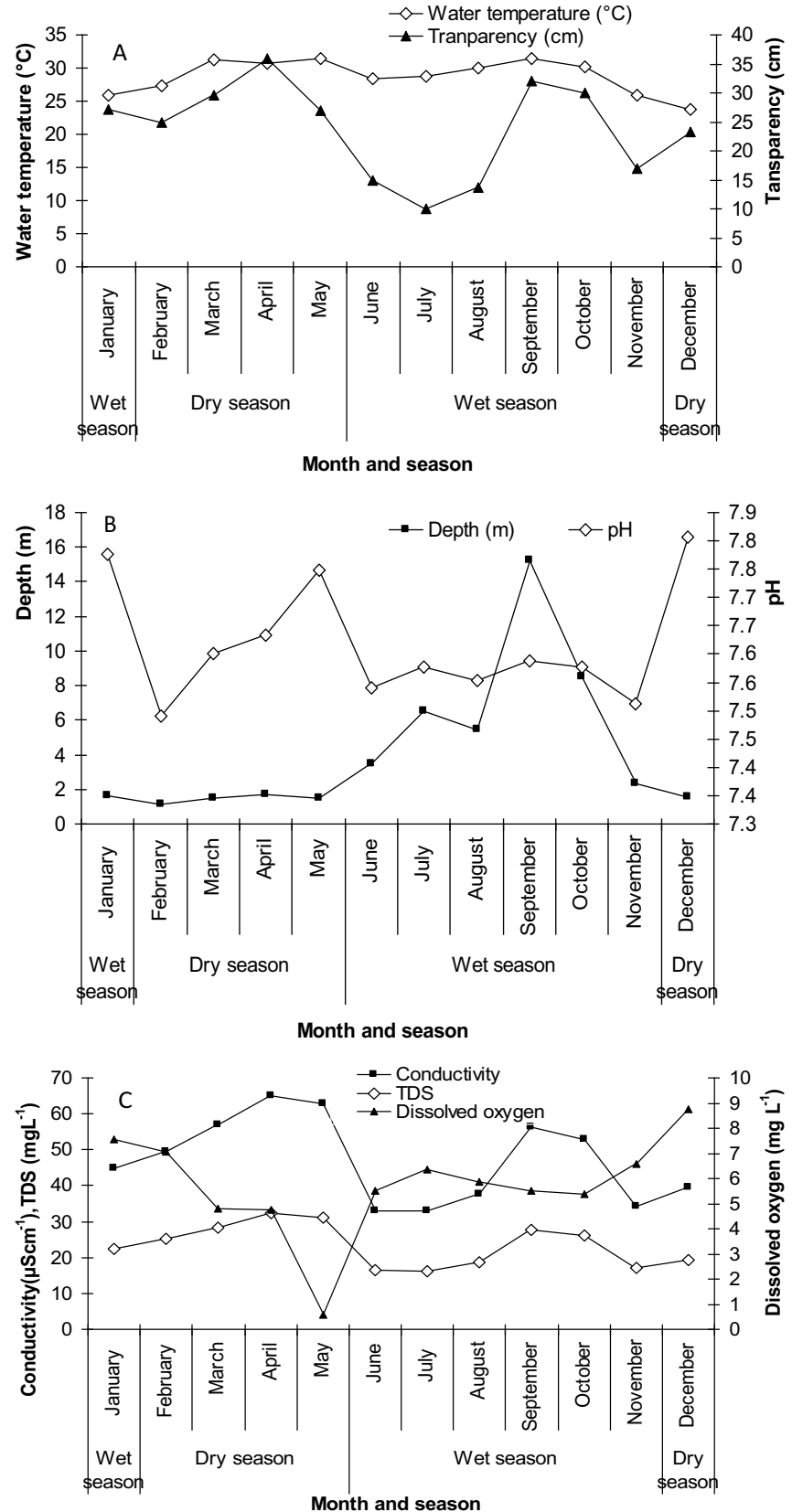

Fig. 5. Monthly variation of environmental variables monitored in the Pendjari River from January to December 2009. A: water temperature $\left({ }^{\circ} \mathrm{C}\right)$ and transparency $(\mathrm{cm})$. B: water depth $(\mathrm{m})$ and $\mathrm{pH}$. C: conductivity $\left(\mu \mathrm{S} \mathrm{cm}^{-1}\right)$, TDS $\left(\mathrm{mg} \mathrm{L}^{-1}\right)$ and dissolved oxygen $\left(\mathrm{mg} \mathrm{L}^{-1}\right)$.

June, and attained the maximum value in September during the flood season $(15.3 \mathrm{~m})$. Conductivity $\left(47.1 \pm 11.7 \mu \mathrm{S} \mathrm{cm}^{-1}\right)$ displayed highest values in April $\left(65.0 \mu \mathrm{Scm}^{-1}\right)$ and then declined to the lowest value $\left(32.8 \mu \mathrm{S} \mathrm{cm}^{-1}\right)$ in July during the rainy season. Total dissolved solids (TDS) showed a similar pattern of fluctuation with conductivity; with the lowest value of $16.2 \mathrm{~m} \mathrm{~L} \mathrm{~L}^{-1}$ in July and the highest value $\left(32.3 \mathrm{mg} \mathrm{L}^{-1}\right)$ in April $\left(23.4 \pm 5.8 \mathrm{~m} \mathrm{~L}^{-1}\right)$. Dissolved oxygen varied from $0.6 \mathrm{mg} \mathrm{L}^{-1}$ in May to $8.6 \mathrm{mg} \mathrm{L}^{-1}$ in December $\left(5.7 \pm 2.0 \mathrm{mg} \mathrm{L}^{-1}\right.$ ) (Fig. $5 \mathrm{C}$ ). This indicates anoxic conditions in May and is probably associated with juvenile mortality. 
Table 2. Values of von Bertalanffy growth parameters of freshwater mussels (Unionoida) belonging to the Etheriidae, Iridinidae and Unionidae families.

\begin{tabular}{|c|c|c|c|c|}
\hline $\begin{array}{l}\text { Family } \\
\text { Species }\end{array}$ & $K\left(\right.$ month $\left.^{-1}\right)$ & $L_{\infty}(\mathrm{mm})$ & Study area & Source \\
\hline \multicolumn{5}{|l|}{ Etheriidae } \\
\hline \multicolumn{5}{|l|}{ Iridinidae } \\
\hline Mutela rostrata & $0.048-0.179$ & $59.3-63.2$ & Lake Chad (Tchad) & Lévêque (1971) \\
\hline \multicolumn{5}{|l|}{ Unionidae } \\
\hline Caelatura aegyptiaca & $0.114-0.152$ & $26.8-33.8$ & Lake Chad (Tchad) & Lévêque (1971) \\
\hline Caelatura teretiuscula & $0.094-0.200$ & $25.5-27.3$ & Lake Chad (Tchad) & Lévêque (1971) \\
\hline \multicolumn{5}{|l|}{ Margaritiferidae } \\
\hline
\end{tabular}

Although significant monthly variations of environmental variables $(p<0.05)$ were recorded, only water transparency showed a significant negative correlation with the mean shell height of small-sized oysters $(r=-0.8285 ; p<0.05)$. However, no significant effect of hydrobiological variables was reported on the growth rate of small-sized oysters. In contrast, all abiotic factors displayed a weak relationship with the mean shell height and growth rate of large-sized oysters (Spearman rank correlation test, $p>0.05$ in all cases).

\section{Discussion}

\section{1 von Bertalanffy growth parameters: implications for oyster culture}

The VBGF theoretical model used for other bivalves (Mason et al., 1998) proved to be a useful tool to estimate growth parameters for the freshwater E. elliptica oyster. However, the validity of estimated VBGF parameters remained mostly limited to the targeted oyster size range (Lévêque and Pointier, 1976). Etheria elliptica belongs to the order Unionoida, also known as freshwater mussels (Graf and Cummings, 2006). A comparison with VBGF growth parameters of African freshwater mussels belonging to Iridinidae and Unionidae families (Order Unionoida) and pearl oysters (Margariferidae: Unionoida; Graf and Cummings, 2006) provided useful information on bivalve dynamics and potential for culture (Hastie et al., 2000; Adjei-Boateng and Wilson, 2012). Earlier in the last century, Anthony (1907) reported slow growth of juvenile E. elliptica. In the current study, our estimated VBGF growth coefficients $K=0.1026$ month $^{-1}$ (small-sized oysters), $K=0.0221$ month $^{-1}$ (largesized oysters) and $K=0.0718 \mathrm{month}^{-1}$ (all sizes pooled, Table 1) were within the range of values $(K=0.048-$ 0.200 month $^{-1}$ ) reported by Lévêque (1971) for freshwater mussels (Iridinidae and Unionidae) reared in cages in Lake Chad. Moreover, the overall growth coefficient $(K=0.0718$ month $^{-1}$ ) for E. elliptica was similar to that for the pearl oyster
Pinctada fucata (Margaritiferidae) reared in India (Chellam, 1988) (Table 2). This indicates a higher growth rate than freshwater mussels (Unionoida) of European waters which exhibit a slower growth rate $\left(K=0.107-0.134 \mathrm{~mm} \mathrm{year}^{-1}\right)$ (Hastie et al., 2000; Haag, 2009). Our findings confirm the trend that smaller individuals $\left(K=0.1026\right.$ month $\left.^{-1}\right)$ grow faster than larger specimens $\left(K=0.0221\right.$ month $\left.^{-1}\right)$ reported for E. elliptica in Ghana (Ampofo-Yeboah, 2000) and freshwater mussels and bivalves in general (Wells and Jernakoff, 2006; Cáceres-Puig et al., 2007). Energy allocation to gonad production in large specimens likely explains widely observed trend in bivalves (Mason et al., 1998; Hastie et al., 2000). However, given the early mortality of the small-sized oysters, further studies are required on the growth parameters of small oysters.

In the current survey, the survival of small oysters $(11 \%)$ was lower than that of large oysters $(79 \%)$ for the first 6 months of the experimental period, which contrasts with a similar growth experiment for juvenile E. elliptica in the White Volta and Oti River in Ghana, where survival rates remained high (97\%) after a similar period (Ampofo-Yeboah, 2000). In this study, all small oysters died in July whereas the survival rate of large oysters declined to $24.6 \%$ after 12 months (December). This higher mortality was likely due to disturbance by fishermen as previously reported by Lévêque (1971). However, our findings are in accordance with Buddensiek (1995) who observed that the survival rate of freshwater mussels depends on their initial size and a higher mortality rate among juvenile mussels. Higher mortality could be attributed to the effect of siltation on young oysters at the onset of the rainy season in June (Kamara, 1982). Therefore, large-sized oysters should likely be recommended for traditional farming. Indeed, Anthony (1907) observed the death of E. elliptica specimens covered by silt owing to arrival of heavy rains which agrees with our results for small E. elliptica. According to Urban (2000), heavy rainfall increased silt levels and adversely affected the survival of young bivalves. Consequently, sites with rocky or hard bottoms should be chosen for extensive 
Table 3. Growth rate, height increments and growth period of E. elliptica in the Pendjari River compared to mangrove Crassostrea gasar oysters and other bivalves in the world.

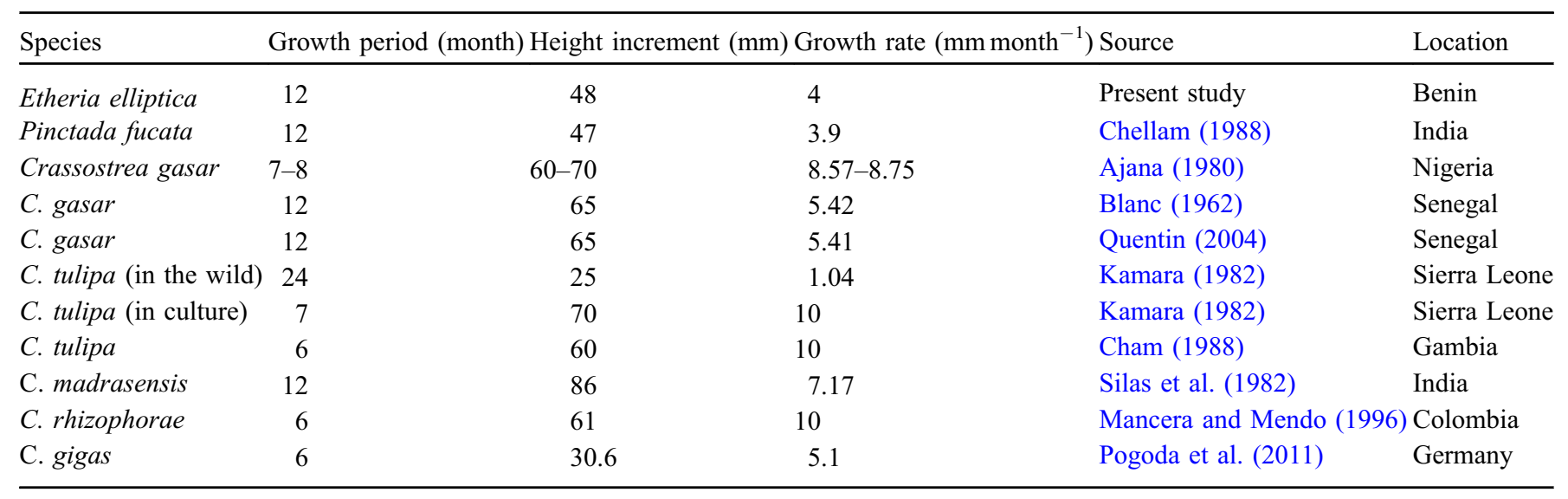

culture rather than sandy and muddy locations. Moreover, previous studies have demonstrated that anoxic waters have potentially detrimental effects on juvenile oyster survival. Tolerance to anoxia increases with body size in oysters (Stickle et al., 1989; Baker and Mann, 1992). Therefore, anoxic conditions recorded at the end of the dry season in the Pendjari River could partly explain the high mortality of small-sized oysters.

However, conditions leading to juvenile oyster mortality are usually avoided for traditional culture. Traditional oyster farming methods use spat collectors made of local materials deployed in selected habitats (Nikolić et al., 1976; Gilles, 1992). After settlement, juvenile oysters are relocated to farming areas with environmental conditions suitable for oyster growth. These include water depth, hard bottom substrates, dissolved oxygen, velocity of water currents, food availability and freedom from pollution (Nikolić et al., 1976). In traditional culture, juvenile oysters are handled infrequently, and anthropogenic influence is minimal. Therefore, as in natural conditions, mortality of small oysters after settlement is limited in traditional farming sites that meet the basic requirements for oyster growth (Diadhiou, 1995). In this light, the high survival rate $(97 \%)$ reported for E. elliptica juveniles in the Volta River study indicated that small oysters can thrive and survive in culture (Ampofo-Yeboah, 2000), and the high mortality recorded in the current study could be considered as a peculiar case, mainly due to unusual adverse conditions (muddy bottom, anoxia during the dry season, frequent handling, etc.). Consequently, potential sites for traditional farming of E. elliptica are stony habitats in running and well-oxygenated waters. Habitats with suitable conditions for oyster culture are common along the Pendjari River. Such habitats often host huge colonies of E. elliptica (Akélé, 2015). However, further studies are required to investigate both the optimal juvenile size for oyster culture and the required habitat conditions for traditional farming in the Pendjari River.

In Ghana, juvenile E. elliptica of the initial size range $(12-19 \mathrm{~mm})$ reared in cages over 6 months displayed a mean height growth increment ranging from $3.50 \mathrm{~mm}$ to $4.07 \mathrm{~mm}$ in the White Volta and $2.32 \mathrm{~mm}$ to $3.21 \mathrm{~mm}$ in the Oti River (Ampofo-Yeboah, 2000). In this study, small-sized oysters (initial range: $12-34 \mathrm{~mm}$ ) exhibited a slightly higher growth increment $(5.1 \mathrm{~mm})$ after five months. The mean height increment $(3 \mathrm{~mm})$ of large-sized oysters recorded after six months in the Pendjari River was similar to the range reported in the Oti River (Ampofo-Yeboah, 2000). Conversely, juveniles of the sister family (Iridinidae) exhibited faster growth in comparison to this freshwater oyster (Kenmuir, 1980; Table 3). According to Mason et al. (1998), differences in bivalve growth rates are likely due to genetic origin.

Overall, in the Pendjari River, the estimated growth rate of E. elliptica $\left(4 \mathrm{~mm}\right.$ month $\left.^{-1}\right)$ is close to values reported for many cultivated oysters (Chellam, 1988; Quentin, 2004; Pogoda et al., 2011; Table 3). Since E. elliptica displayed a growth rate similar to many cultured tropical oysters, it should be concluded that this freshwater oyster has potential as a cultured species in the Pendjari River.

Growth rates can also be used to estimate the time required to reach marketable size (Urban, 2000). In the Pendjari River, the times needed for freshwater E. elliptica oysters to reach maturity were between 1.4 years and 1.8 years (Table 1). To prevent overexploitation, minimum marketable sizes should be at least greater than size at female maturity $(65 \mathrm{~mm})$. These results are in accordance with those for other African freshwater mussels (Unionoida) including Asptharia walberghi (Iridinidae) which reaches sexual maturity between 60 and $65 \mathrm{~mm}$ and Mutela dubia (Iridinidae) which begins brooding at $52 \mathrm{~mm}$ (1-2 years of age, Kenmuir, 1980). Etheria elliptica exhibited a better growth rate than the freshwater $G$. paradoxa clam which attained maturity $(64.5 \mathrm{~mm})$ at six years of age (Adjei-Boateng and Wilson, 2012). We believe the time needed by E. elliptica to reach maturity could decrease by reducing specimen handling. Indeed the growth rate of oysters has been shown to decrease markedly with repeated handling for measurement (Haag, 2009). Therefore, the natural growth rate of E. elliptica is likely higher than current estimated values. Overall, E. elliptica grew slower than other tropical oysters which can reach market size in less than one year, often in as little as six months (Angell, 1986; Vakily, 1992). Despite a slower growth rate, specimens of E. elliptica in natural populations can reach large sizes $(133 \mathrm{~mm})$ as observed in the Pendjari River. In addition, E. elliptica has a broad distribution in tropical Africa and Madagascar (Yonge, 1962) and thus meets the two main criteria for species suitable for aquaculture (Angell, 1986). 
Traditional culture of bivalves under natural conditions has been widely promoted in West Africa, especially for the mangrove oyster Crassostrea gasar in Senegal (Diadhiou, 1995; Thiam et al., 2011), in Gambia (Crow and Carney, 2013) and for the freshwater $G$. paradoxa clam in Ghana (AdjeiBoateng and Wilson, 2012). These previous successes should contribute greatly to enabling future culture of E. elliptica in the Pendjari River.

In North Benin, E. elliptica is currently harvested for food and as an income source by riverside populations. After fish species, E. elliptica oysters constitute the second largest resource collected in the Pendjari Biosphere Reserve (Kiansi, 2011). Moreover, its shell is especially used as a source of calcium in poultry feed. Therefore, oyster culture will improve the livelihood of local people as a source of affordable protein, increase their income and reduce poaching activities within the Pendjari Biosphere River (Vodouhê et al., 2009; Kiansi, 2011). Because oysters are filter feeders, their culture may also contribute to water purification.

\subsection{Hydrobiological variables affecting oyster growth}

Water temperature remains fairly constant in tropical Africa and is favorable for bivalve growth throughout the year (Welcomme, 1985). In the tropics, most freshwater molluscs can survive within the temperature range of $10-42{ }^{\circ} \mathrm{C}$ (Purchon, 1977). Hence, the water temperature values in Pendjari waters $\left(23.8-31^{\circ} \mathrm{C}\right.$ with a mean of $\left.28.7^{\circ} \mathrm{C}\right)$ reported in the present study are favorable for growth of E. elliptica. Likewise, $\mathrm{pH}$ was fairly constant $(7.6 \pm 0.1)$ over the year and indicated a tendency towards alkalinity, which appears to be suitable for the survival of freshwater oysters (Welcomme, 1985). According to Quayle (1980), oxygen levels recorded during this study (mean $\pm \mathrm{SD}: 5.7 \pm 2.0 \mathrm{mg} \mathrm{L}^{-1}$ ) are favorable for the growth of the freshwater oysters. Conductivity levels in the Pendjari River $\left(47.1 \pm 11.7 \mu \mathrm{S} \mathrm{cm}^{-1}\right)$ fell within the range measured $\left(41-124 \mu \mathrm{S} \mathrm{cm}^{-1}\right)$ in the Volta system by Welcomme (1985). Porga, the experimental site, was shallow (depth: 1.1-1.6 m) during the dry season (December-May) and for almost half the year. According to Ahouansou Montcho (2011), mean water depth increases significantly from upstream to downstream. During the dry season, the river is almost dry (water depth: $0.1-0.5 \mathrm{~m}$ ) in upstream stations. Many oyster colonies were found out of the water and individuals were found dead (Akélé, 2015). Therefore, downstream stations, including the experimental site, seem appropriate for oyster culture throughout the year.

Although significant differences were reported among monthly means, only transparency significantly affected height increment of small-sized oysters $(r=-0.8285 ; p<0.05)$, indicating that lower transparency is associated with faster growth, probably due to higher concentrations of suspended particles and phytoplankton in the river (Costa et al., 2011).

\section{Conclusion}

In conclusion, E. elliptica is a suitable candidate for traditional culture owing to its large natural size in the Pendjari River. This species had a growth rate similar to that of other commercially cultured bivalves. As a filter feeder, this freshwater oyster may not require supplementary food in culture. Moreover, hydrological variables in the Pendjari River favor oyster survival and growth. Further studies will be required to assess spat collection, and to estimate optimal rearing size and appropriate rearing sites.

Acknowledgments. This study was funded by "BIOTA-West Africa". Special thanks are due to Dominique Sambieni, our guide and Dieudonné for cage surveillance and for assistance during data collection. We also thank Porga fishermen for their collaboration in the field.

\section{References}

Abell PI, Amegashitsi L, Ochumba PBO. 1996. The shells of Etheria elliptica as recorders of seasonality at Lake Victoria. Palaeogeogr Palaeoclimatol Palaeoecol 119: 215-219.

Adjei-Boateng D, Wilson JG. 2012. Population dynamics of the freshwater clam Galatea paradoxa from the Volta River, Ghana. Knowl Manage Aquat Ecosyst 405: 09.

Adjei-Boateng D, Wilson GJ. 2013. Age determination and growth rate of the freshwater clam Galatea paradoxa (Born 1778) from the Volta River Estuary, Ghana. J Aquat Sci 1: 31-38.

Ahouansou Montcho S. 2011. Diversité et exploitation des poissons de la rivière Pendjari (Benin, Afrique de l'Ouest), Thèse de Doctorat. Benin: Université d'Abomey-Calavi, 204 p.

Ajana AM. 1980. Fishery of the mangrove oyster, Crassostrea gasar, Adanson (1757) in the Lagos area, Nigeria. Aquaculture 21: 129-137.

Akélé GD. 2015. Biologie, exploitation et conservation de l'huître d'eau douce Etheria elliptica (Lamarck, 1807) (Mollusca: Bivalvia: Etheriidae) à la rivière Pendjari au Bénin, Thèse de Doctorat. Bénin: Université d'Abomey-Calavi.

Akélé GD, Agadjihouédé H, Mensah GA, Lalèyè PA. 2015. Population dynamics of freshwater oyster Etheria elliptica (Bivalvia: Etheriidae) in the Pendjari River (Benin-Western Africa). Knowl Manage Aquat Ecosyst 416: 06.

Ampofo-Yeboah A. 2000. Aspects of the fishery, ecology and biology of the freshwater oyster (Etheria $s p$. Lamarck, 1807) in northern Ghana. Master of Philosophy degree in Zoology University of Cape Coast, $42 \mathrm{p}$.

Ampofo-Yeboah A, Owusu-Frimpong M, Yankson K. 2009. Gonad development in the freshwater oyster Etheria elliptica (Bivalvia: Etheriidae) in northern Ghana. Afr J Aquat Sci 34: 195-200.

Angell CL. 1986. The biology and culture of tropical oysters. ICLARM: International Center for Living Aquatic Resources Management, Manila, Philippines. Stud Rev 13: 42.

Ansa EJ, Bashir RM. 2007. Fishery and culture potentials of the mangrove oyster (Crassostrea gasar) in Nigeria. Res J Biol Sci 2: 392-394.

Anthony R. 1907. Etude monographique des Aetheriidae (Anatomie, Morphogénie, Systématique). Ann Soc Zool Malac Belg 41: 322-430.

Baker SM, Mann R. 1992. Effects of hypoxia and anoxia on larval settlement, juvenile growth, and juvenile survival of the oyster Crassostrea virginica. Biol Bull 182(2): 265-269.

Barry B, Obuobie E, Andreini M, Andah W, Pluquet M. 2005. The Volta River Basin, Comprehensive Assessment of Water Management in Agriculture. Comparative study of river basin development and management. International Water Management Institute (IWMI), 198 p. 
Blanc A. 1962. Etude de l'huître des palétuviers (Gryphea gasar Adanson). Sénégal: Rapport de la Direction des Pêches, 78 p.

Buddensiek V. 1995. The culture of juvenile freshwater pearl mussels Margaritifera margaritifera L. in cages: a contribution to conservation programmes and the knowledge of habitat requirements. Biol Conserv 74: 33-40.

Cáceres-Puig JI, Abasolo-Pacheco F, Mazón-Suastegui JM, Maeda-Martínez AN, Saucedo PE. 2007. Effect of temperature on growth and survival of Crassostrea corteziensis spat during late-nursery culturing at the hatchery. Aquaculture 272: 417-422.

Cham MA. 1988. Trials in the culture of the West African mangrove oyster (Crassostrea tulipa) in Gambia. Bouaké: Paper presented at the aquaculture Research Workshop, $12 \mathrm{p}$.

Chellam A. 1988. Growth and biometric relationship of pearl oyster Pinctada fucata (Gould). Indian J Fish 35: 1-6.

Costa VB, Sousa EB, Pinheiro SCC, Pereira LCC, Costa RM. 2011. Effects of a high energy coastal environment on the structure and dynamics of phytoplankton communities (Brazilian Amazon littoral). J Coast Res 64: 354-358.

Crow B, Carney J. 2013. Commercializing nature: mangrove conservation and female oyster collectors in the Gambia. Antipode 45: 275-293.

Diadhiou HD. 1995. Biologie de l'huître de palétuvier Crassostrea gasar (Dautzenberg) dans l'estuaire de la Casamance (Sénégal): reproduction, larves et captage du naissain. Thèse de doctorat de l'Université de Bretagne Occidentale, Brest (France), 122 p.

Gilles S. 1992. Observations sur le captage et la croissance de l'huitre creuse ouest-africaine, Crassostrea gasar, en Casamance, Sénégal. Ifremer, Actes de Colloques 14: 71-88.

Graf DL, Cummings KS. 2006. Palaeoheterodont diversity (Mollusca: Trigonoida + Unionoida): what we know and what we wish we knew about freshwater mussel evolution. Zool J Linn Soc 148: 343-394.

Gulland JA. 1969. Manuel des méthodes d'évaluation des stocks d'animaux aquatiques. Première partie : Analyse des populations. Manuel de Science Halieutique FRS/M4, 160 p.

Haag WR. 2009. Extreme longevity in freshwater mussels revisited: sources of bias in age estimates derived from mark-recapture experiments. Freshwat Biol 54: 1474-1486.

Hastie LC, Young MR, Boon PJ. 2000. Growth characteristics of freshwater pearl mussels, Margaritifera margaritifera (L.). Freshwat Biol 43: 243-256.

Ikpi GU, Offem BO. 2012. Fishery and the tourism potential of Agbokum waterfalls, Nigeria. J Wat. Resour Prot 4: 733-745.

Kamara AB. 1982. Preliminary studies to culture mangrove oysters, Crassostrea tulipa, in Sierra Leone. Aquaculture 27: 285-294.

Kenmuir DHS. 1980. Aspects of the biology and population dynamics of freshwater mussels in Lake Kariba and Lake Mcilwaine, $\mathrm{PhD}$ Thesis. Zimbabwe: University of Natal, 368 p.

Kiansi Y. 2011. Cogestion de la Reserve de Biosphere de la Pendjari : Approche concertee pour la conservation de la biodiversite et le developpement economique local. These de doctorat de l'Universite d'Abomey-Calavi, $274 \mathrm{p}$.

King RP. 2000. Population structure, growth performance and mortality rates of the freshwater clam Galatea paradoxa (Born 1778) in Nun River, Nigeria. Arch Fish Mar Res 48: 21-30.

Lango-Reynoso F, Chávez-Villalba J, Cochard JC, Le Pennec M. 2000. Oocyte size, a means to evaluate the gametogenic development of the Pacific oysters Crassostrea gigas (Thunberg 1793). Aquaculture 190: 183-199.

Lévêque C. 1971. Equation de Bertalanffy et croissance des mollusques benthiques du lac Tchad. Cahiers ORSTOM Sér Hydrobiol 5: 263-283.
Lévêque C, Pointier JP. 1976. Study of the growth of Biomphalaria glabrata (Say) and other Planorbidae in Guadeloupe (West Indies). Ann Trop Med Parasitol 70: 199-204.

Mancera E, Mendo J. 1996. Population dynamics of the oyster Crassostrea rhizophorae from the Cienaga Grande de Santa Marta, Colombia. Fish Res 26: 139-148.

Mason CJ, Reidb DD, Nella JA. 1998. Growth characteristics of Sydney rock oysters Saccostrea commercialis in relation to size and temperature. J Exp Mar Biol Ecol 227: 155-168.

Nikolić M, Bosch A, Alfonso S. 1976. A system for farming the mangrove oyster (Crassostrea rhizophorae Guilding, 1828). Aquaculture 9: 1-18.

Paterson KJ, Schreider MJ, Zimmerman KD. 2003. Anthropogenic effects on seston quality and quantity and the growth and survival of Sydney rock oyster (Saccostrea glomerata) in two estuaries in NSW, Australia. Aquaculture 221: 407-426.

Poda JN. 1992. L'huitre des rivières: Distribution, rôle dans l'alimentation et la pharmacologie locales au Burkina Faso. Science et Technique: Série Sciences Naturelles, CNRST 3: 5-16.

Pogoda B, Buck BH, Hagen W. 2011. Growth performance and condition of oysters (Crassostrea gigas and Ostrea edulis) farmed in an offshore environment (North Sea, Germany). Aquaculture 319: 484-492.

Pouvreau S, Tiapari J, Gangnery A, et al. 2000. Growth of the blacklip pearl oyster, Pinctada margaritifera, in suspended culture under hydrobiological conditions of Takapoto lagoon (French Polynesia). Aquaculture 184: 133-154.

Purchon RD. 1977. The biology of the molluscs, 2nd ed. New York, NY, USA: Pergamon Press, 560 p.

Quayle DB. 1980. Tropical oysters: culture and methods. Ottawa, Canada: International Development Center, T.S. 17e. 80 p.

Quentin D. 2004. Mise en place d'une ostréiculture villageoise pour Crassostrea gasar A., l'huître de palétuvier. Faculté Universitaire des Sciences Agronomiques de Gembloux, mémoire d'étude, 2003-2004.

Silas EG, Alagarswami K, Narahimhan KA, Appukuttan KK, Muthiah P. India. In: Davy FB, Graham M, eds. Bivalve culture in Asia and the Pacific. Workshop Proceedings, 1982. Ottawa, Canada: International Development Research Centre, pp. 34-43.

Sinsin B, Tehou AC, Daouda I, Saidou A. 2002. Abundance and species richness of larger mammals in Pendjari National Park in Benin. Mammalia 66(3): 369-380.

Stickle WB, Kapper MA, Liu LL, Gnaiger E, Wang SY. 1989. Metabolic adaptations of several species of crustaceans and molluscs to hypoxia: tolerance and microcalorimetric studies. Biol Bull 177(2): 303-312.

Thiam N, Clotilde Ba FL, Sy MD. 2011. Inventaire, étude biométrique et variabilité de l'abondance locale de Crassostrea gasar (Adanson, 1891) dans deux sites de la Réserve de Biosphère du Delta du Saloum. J Sci Hal Aquat 4: 134-142.

Urban HJ. 2000. Culture potential of the pearl oyster Pinctada imbricata from the Caribbean. II. Spat collection, and growth and mortality in culture systems. Aquaculture 189: 375-388.

Vakily JM. 1992. Determination and comparison of bivalve growth rate with emphasis on Thailand and other tropical areas. ICLARM Tech Rep 36: 125.

Van Damme D. 2011. Etheria elliptica. In: IUCN 2012. IUCN Red List of Threatened Species. Version 2012.2. www.iucnredlist.org (downloaded on 2013/21/03).

Vodouhê GF, Coulibaly O, Greene C, Sinsin B. 2009. Estimating local values of non-timber forest products to Pendjari Biosphere Reserve dwellers in Benin. Econ Bot 63: 397-412. 
von Bertalanffy L. 1938. A quantitative theory of organic growth. Hum Biol 10: 181-213.

Walford LA. 1946. A new graphic method of describing the growth of animals. Biol Bull 90(2): 141-147.

Welcomme RL. 1985. River fisheries. FAO Fisheries Technical Paper 262. Rome: FAO, $131 \mathrm{pp.}$
Wells FE, Jernakoff P. 2006. An assessment of the environmental impact of wild harvest pearl aquaculture (Pinctada maxima) in Western Australia. J Shellfish Res 25: 141-150.

Yonge CM. 1962. On Etheria elliptica Lam. and the course of evolution, including the assumption of monomyarianism, in the family Etheriidae (Bivalvia: Unionacea). Philos Trans $R$ Soc Lond B 244: 423-458.

Cite this article as: Akélé GD, Ahouansou Montcho S, Lalèyè PA. 2017. Growth of freshwater Etheria elliptica oyster (Lamarck, 1807) reared in cages in the Pendjari River (Benin, West Africa). Aquat. Living Resour. 30: 17 